\title{
Transitional Economies Of Europe And The Development Of Financial Reporting Standards: A Look At The Correlation Between A Successful Economic Transition And The Development Of Financial Reporting Standards And Laws
}

Tristan Gartin, West Virginia University, USA Evan Shroyer, West Virginia University, USA

Presha E. Neidermeyer, Ph.D. CPA, West Virginia University, USA

\begin{abstract}
During the late 1980s to early 1990s, countries around the world, such as Czechoslovakia, Lithuania, Poland, and Russia, began transitioning their economies from planned socialism, more specifically, Communism, to free market capitalism. The purpose of this paper is to analyze these economies of Europe and Asia and their adoption of appropriate financial reporting. With Poland and the Czech Republic, there is a positive correlation between a successful transition and the number of financial reporting standards implemented. However, deviations from this correlation can arise, such as in the cases of Lithuania and Russia, where the promulgation of accounting standards is delayed or there is no organization to regulate the implementation of the accounting standards.
\end{abstract}

Keywords: transitional economies, international accounting, national accounting, communism, the Czech Republic, Poland, Lithuania, Russia

\section{INTRODUCTION}

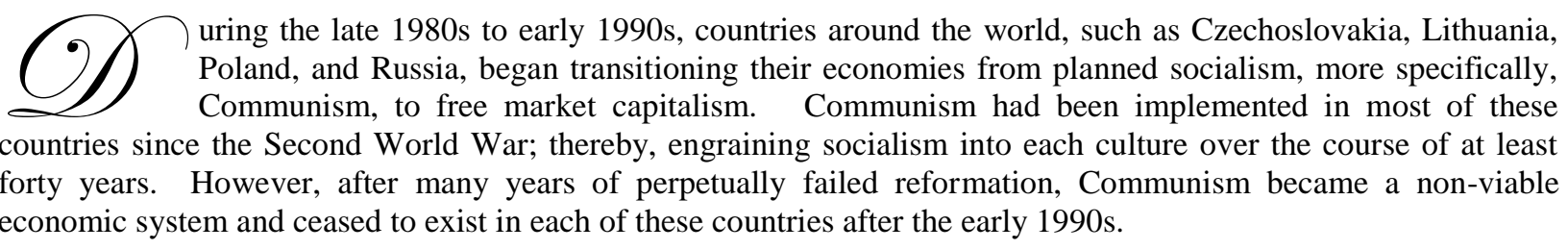

Communism is starkly different from a capitalism is several ways. For one, all productive resources, except for labor, in the economy are owned by the state; whereas, in capitalist economies, these are owned by the people of the economy. In capitalist economies, companies may be privately held by individuals, or owned by several people, such as the case of partnerships or publicly held corporations. Therefore, in a communist economy, the state has complete control over all decision-making and production of output (Trumbull, 2008). 
Given that all output is planned by national officials, Communism is inherently a command economy in order to reach higher and higher target output levels through taught planning. As a result, this type of economy is very centralized in terms of decision-making, and is quite bureaucratic. In contrast, each individual firm in a capitalist economy makes decisions based on the corporate objectives and in response to the decisions made by other firms (Trumbull, 2008).

Another key element of Communism is the idea of growth through extensive means rather than intensive means. Through massive increases in resources instead of productivity, large-scale industrialization occurs in order to reach determined levels of output for the economy. On the other hand, capitalist economy achieves growth via extensive as well as intensive means. As a result, this economy does not have large-scale industrial operations like a communist country because innovation and increases in productivity allow the economy to achieve higher and higher output (Trumbull, 2008).

Normally, the general accounting methods that accompanied planned economies are based around very different goals and objectives than those of a capitalist economy with those Communist objectives being focused around centralized decision-making, rapid economic growth through increasingly higher levels of output via extensive means, and industrialization. Therefore, when transition began for Czechoslovakia, Lithuania, Poland, and Russia, financial reporting was significantly impacted. The pre-transitional accounting practices could not support a free market economy. As a result, economic transition necessitated a transition in financial reporting and auditing as well.

The purpose of this paper is to analyze rapidly transitioned economies of Europe and Asia and their adoption of appropriate financial reporting, since these economies would have required significant and prompt changes in financial reporting. Therefore, our investigation will focus on the countries of Czech Republic, Lithuania, Poland, and Russia and not economies like Hungary and China, whose transition has been to more of a market-socialist economy, which still has aspects of central planning.

Essentially, all of the rapidly transitioning countries were starting from the scratch with their financial reporting and auditing standards. No former communist country had an advantage over another because the communist style of accounting was so vastly different that there were not many similarities between countries. As a result, we will analyze the financial accounting of each country after the beginning of transition.

Our intention is to prove that there is a positive correlation between the development of financial reporting and auditing standards promulgated in a transitional economy and the success of the country's transition. Our approach will analyze the correlation between the number of International Financial Reporting Standards (IFRS) and other accounting standards adopted for a country compared to its GDP (in purchasing power parity), unemployment, and inflation rates over the course of the transitional period. Overall, this will show us the correlation between how well the country started being a productive economy again in relation the number of reporting standards adopted and thus whether more financial reporting standards led to a higher level of growth and stability.

In our paper, we will review over the information we have gathered to conduct our research. The literature review will analyze the economic and financial accounting data and our interpretations thereof. In addition, we will describe the pre-transition accounting methods used by Communist countries as well as what economic transition is, how it is measured for the purposes of our investigation, and how each country fared with regard to economic transition. We then elaborate on how financial reporting standards developed as each country moved through transition and, subsequently, the current situation of financial reporting standards in each country. Lastly, we compare the success of each country's transition to its development of accounting regulations and propose whether or not there is a correlation between the two variables.

\section{LITERATURE REVIEW}

The majority of the economic background for our research came from a college level course taken by one of the authors during the spring semester of 2008, an academic paper, and a book of world economic statistics. Transitional Economies of Europe, which studied the economic impact of transitioning from a centrally planned 
type of economy to free-market economy, was taught by William Trumbull, a professor of Economics at West Virginia University. The information gleaned from this course provided a breadth of information applicable to our research, such as changes in gross domestic product (GDP), inflation, unemployment, and other supporting information. Additionally, Comparing Apples: Normalcy, Russia, and the Remaining Post-Socialist World, written by Trumbull and Peter Leeson, gave insight as to which countries we would scrutinize based on their analysis of Angus Maddison's data in Development Centre Studies The World Economy: Historical Statistics.

The Russian Revolution in Accounting and Auditing, by Adolph Enthoven, and Comparative International Accounting, written by and Christopher Nobes and Robert Parker gave us a plethora of information on accounting laws, regulations and standards that were enacted in the transitional economies we've selected. More specifically, Accounting Reform in Transition and Developing Economies, edited by Robert McGee, elaborated on the years in which accounting legislation was enacted in the Czech Republic and Lithuania, thereby allowing us to make correlations with the economic data provided by Trumbull, Leeson, and Maddison. Lastly, IASPlus, a Deloitte, LLP, website, provided us with current information regarding each country's position regarding the adoption of IFRS.

\section{PRE-TRANSITION ACCOUNTING METHODS}

In capitalist countries, the underlying principles of financial accounting are known as the conceptual framework. The conceptual framework ensures consistent application of standards and guidance for financial statements. The users of this financial information are both internal and external to the corporation. However, in socialist countries, the accounting system is useful to central planners and central planners alone. In a centrally planned economy, the information received from accounting is used to benefit central planners, guard state-owned property, and for control of the economy (Garrod \& McLeay, 1996). Essentially, national accounting methods in socialist countries are somewhat like managerial accounting in capitalist countries. When state ownership is present, the main concern is on the budget and output.

The budget revolves around two sectors in the economy: the productive sector, which produces goods and services, and the non-productive sector, which includes allocations to individual citizens and the general public (Garrod \& McLeay, 1996). The national accountants would analyze the productive sector and calculate national income, most likely on a cash-basis of accounting, from the results and make allocations to the non-productive sector. However, the "focus was not on income because there was never a going-concern issue. Therefore, more importance was placed on accounting for output and not on the nature and definition of income (Garrod \& McLeay, 1996)."

Socialist countries operate using a standardized chart of accounts and principles, which are enforced by law. Financial information of state-owned entities is not publicized and is used to produce statistics for central planners. This contributes to little or no transparency, which is needed for international standards adoption.

According to Garrod and McLeay (1996),

At the level of the union republics, [governmental standard-setting and regulation] bodies were only channels for the dissemination of central accounting legislation. Of course, when accounting practice depends on the politics of the Communist Party and Soviet Government, rather than on accounting theory and economic laws, it is impossible to have an accounting system useful for real economic life.

\section{DESCRIPTION OF TRANSITION AND ITS IMPACTS ON FINANCIAL REPORTING}

A running theme in centrally planned economies is one of perpetual reform. Prior to transition, all leaders of centrally planned economies implemented reform in order to help make the economies more efficient and effective. The most notable reform of centrally planned economies was Perestroika, the Russian reform in the mid1980s. Perestroika, which allowed elements of free-market economies into the centrally planned economy, was the beginning of the end for Russia. Once multiple reforms begin failing, and a centrally planned economy cannot sustain growth or control, the economy collapses. As a result, transition from centrally planned economy to a free- 
market economy occurs and the focus of accounting shifts from more of managerial type of accounting to a financial reporting type of accounting.

One main difference between capitalist financial accounting and national accounting is the ultimate users of the financial information. The users of national accounting were the central planners, or internal, and was more focused on efficiency and effectiveness of use of resources and output. However, with capitalist countries, the users of accounting information are both internal and external and the focus is on profitability. Accounting standards are promulgated to help bring uniformity to how companies account for their profitability and cash flow. As a result of this difference, a transition from a centrally planned economy to a free-market economy necessitates a transition in the type of accounting used, and by extension the framework and principles utilized in those economies.

In all of the countries we are analyzing, each went through a fast, quick transition to a capitalist economy, also referred to as shock therapy. When a country chooses to shock therapy instead of a gradual transition, laws and policies must be implemented quickly. Since this is the case, accounting standards and policies must also be implemented quickly to accommodate newly privatized businesses who are building capital, which also necessitates a need for financial reporting to owners and investors. Ideally, a country in the midst of an economic transition should quickly implement financial accounting standards, a standard setting body, and a regulation body in order to accommodate for the growing need for accurate financial information.

Another reason for the quick application of accounting standards is because one of the first steps to transitioning is the creation of banks and financial markets. In order to have these function properly, effective controls must be established in the form of accounting standards so that the financial market and banking system will function properly. Banks and financial markets must be able to obtain trust and confidence that their investments are being utilized effectively. Also, investors and creditors also expect a positive return on their investment. If one cannot be obtained, then obviously it is a bad investment.

In addition, accounting laws and standards are implemented to prevent the misuse of investor capital. An effective legal system must be created in order to enforce different regulations, such as laws governing securities. Other different parts of the legal system that must be established which affect companies and accounting are contract law, bankruptcy law, anti-monopoly law, intellectual property law, and property law (Trumbull, 2008). In some countries, the enforcement of some laws, such as bankruptcy, were somewhat lenient until the country pulled out of economic turmoil. For example, "Czech Republic put a hiatus on bankruptcy laws because the revaluation of receivables and payables led to many companies facing certain bankruptcy (Garrod and McLeay, 1996)." However, generally speaking, a transitional economy is prone to corruption and fraud without and effective legal system.

The creation of individual markets is another aspect of transition that affects accounting. In a planned socialist economy, there are no markets; thus, there are no supply and demand curves to establish prices. As a result, central planners must arbitrarily set the prices for goods in the economy. This estimation of prices has absolutely no value in a free-market society because it does not reflect the actual value of a good, which is based on scarcity. Thus, transitional countries must revalue all of the assets that a company owns to the market value because if an asset with the historical cost based on socialist prices, it is irrelevant to any free-market decision making.

Another important aspect of economic transition that affected financial reporting is that of inflation rates during transition. Each country needs to establish accounting standards and regulations on how to prepare financial statements when the country is experiencing very high rates of inflation, or hyperinflation if the inflation rate is above $50 \%$ per year.

Lastly, an effective tax structure needs to be constructed to which affects how companies account for taxes. Since the all income from corporations will no longer belong to the state, a way of generating revenue needs to be established through taxes. Therefore, accounting laws and regulations on taxes will need attention from standard setters. 


\section{ECONOMIC TRANSITION}

In order to evaluate our thesis, we will need to determine the level of success each country had with regard to economic transition. By analyzing the quantitative elements of an economic system, mainly economic growth and stability, we will be able to roughly assess how well each country and its economy transitioned from Communism to capitalism. We can then use this information to compare find whether or not there is a correlation between the success of the country's transition and the development of the country's financial reporting standards.

Through analyzing the change of GDP of a country, an estimate of whether or not the country's economy is contracting or expanding can be established. It is important to note, however, that an economy cannot be evaluated as being successful in its transition by looking at changes from year to year (Trumbull, 2008). Thus, one must look at the trend of the country's GDP over time in order to obtain a better idea of how economic growth fared in relation to the success of a country's transition. We will assess the changes in GDP for Czech Republic, Poland, Lithuania, and Russia over the course of at least 10 years after the beginning of economic transition.

In addition, by looking at the economic stability of each country (i.e., inflation and unemployment), this will further allow us to assess the transition of each country. Prolonged inflation and unemployment in a transitional economy suggests a contracting economy and, therefore, an unsuccessful transition. However, it is expected that each country will have some problems with economic stability while transitioning since this is not uncommon. It is the length of time and severity of inflation and unemployment that will help us assess the transition's success.

\section{Czech Republic}

Communism had been implemented after World War II in Czech Republic (then Czechoslovakia). Czechoslovakia was one of the most rigorously planned economies of the era in which $98 \%$ of all factors of production were state-owned (Trumbull, 2008). However, their economy fell in the late 1980s when it was no longer able to maintain control over the economy and increase output. In addition, there was much public dissent against communist rule in Czechoslovakia. This dissatisfaction led to the Velvet Revolution, which unquestionably factored into the collapse of communist rule in the Republic. Transition for Czechoslovakia began in 1990 with the Czech Republic and Slovakia splitting amicably thereafter in 1993 (Trumbull, 2008).

Generally speaking, the Czech Republic had a very good transition from a centrally planned economy to a free-market economy. The transition period showed a severe decline in GDP in 1991, followed by slight declines in 1992 and 1993 (see Figure 1). The GDP then rebounded from 1994 to 1996 prior to going into a two year recession followed by economic growth through 2005. Except for the slight recession from 1996 to 1998, Czech Republic had a very solid transition in regard to GDP levels (Trumbull, 2006).

Inflation in Czech Republic never reached hyperinflationary levels and decreased consistently over time (see Figure 2). In 1991, inflation reached 36.2\% and later significantly decreased where it stagnated between $8 \%$ and 20\%. After 1998, inflation was less than 5\% through 2005. Czech Republic had one of the best transitions when it came to managing the rate of inflation (Trumbull, 2008).

The anomaly to Czech Republic's successful transition is the unemployment rates experienced as it transitioned (see Figure 3). Czech Republic's unemployment rate was less that 5\% from the beginning of transition through 1998. However, unemployment rose to around 8\% through 2004. This was Czech Republic's weak point with regard to its transition (Trumbull, 2008).

In conclusion, the Czech Republic had an above average transition from Communism to capitalism. GDP rose at respectable levels, and inflation was kept under control. With the only down-side of the Czech Republic's transition being increasingly higher rates of unemployment, we believe that the country qualifies as a successful transitional economy. 


\section{Poland}

Prior to World War II, Poland was a successful capitalist country. Commonly referred to as the "breadbasket of Europe," Poland was a thriving capitalist country before the Soviet Union made Poland a satellite nation following World War II. During its Soviet occupation, what used to be the agricultural hub of Europe now faced severe food shortages. In addition, the resource-scarce nation was unable to achieve extensive growth like other satellite nations. As a result, many Poles were against Communism, including many in the Catholic Church notably, Pope John Paul II. By the end of the 1980s, Communism's influence over Poland was fading and Poles were ready for a change (Trumbull, 2008).

Beginning on January, $1^{\text {st }}, 1990$, Poland began transitioning to a free-market economy. Having been a capitalist country before 1945, Poland's transition was quite successful and widely welcomed among its citizens. Poland suffered a short, yet moderate, economic contraction of $-7.3 \%$ GDP growth in 1991, after which GDP grew between 1.5\% and 7\% through 2005 (Trumbull, 2008). Poland finally returned to pre-transitional GDP levels six years after the beginning of transition, and continued to exceed this level through 2005 (See Figure 1). With regard to transition, Poland was arguably the most successful country, achieving pre-transition levels of GDP in only six years after the beginning of transition (Trumbull, 2006).

In 1991, Poland experienced a very high rate of inflation, 55.2\%. However, as time went on, inflation staggered between 30\% and 40\% from 1992 to 1995, after which inflation steadily decreased. From 2001 through 2005, Poland's inflation rate was consistently below 5\% (See Figure 2). Poland's transitional success in relation to the fluctuation of inflation rates after the beginning of transition has been very good. Except for one year while the country experienced hyperinflation, Poland was able to bring its inflation to a very manageable level (Trumbull, 2008).

The downside to Poland's transition was the unemployment rate. The unemployment rate, on average, actually increased from the beginning of transition through 2005. It held steady at 10\% to 15\% from 1991 to 1999 , after which inflation averaged about 18.5\% through 2005 (See Figure 3). At one point, the unemployment rate almost reached $20 \%$ in 2002 . Typically, with a transitional economy, the unemployment rate with increase over the first few years of transition. After this initial period, the unemployment rate will decline to a much more manageable level. However, this was not the case with Poland. We believe that Poland had one of the worst transitions with regard to managing the unemployment rate after transition (Trumbull, 2008).

Overall, Poland had one of the most successful transitions of the former communist economies of Europe. Poland had a very strong recovery of GDP as well as a well-maintained post-soviet inflation rate. However, the drawback to Poland's transition is the rise in the unemployment rate. But, we feel that Poland still had a great transition, good enough to be considered successful.

\section{Lithuania}

Previously an independent nation, Lithuania was annexed by the Soviet Union during World War II. As a result, Lithuania remained integrated under the Soviet ruled and planned economy until their secession in March of 1990. Lithuania was first among the Soviet states to declare its independence. The Soviet Union did not recognize Lithuania as a separate country until months before the Soviet Union's collapse. "Lithuania subsequently restructured its economy for integration into Western European institutions (CIA World Factbook)." Lithuania's transition to a capitalist economy began in 1991 (Trumbull, 2006).

Lithuania's GDP during transition slumped for the first three years of transition, but then recovered, achieving moderate increased of GDP. However, during the first 12 years of transition, it did not return to pretransition levels of GDP (Trumbull, 2006). During the first year of transition, GDP levels fell by $21 \%$, followed by $16 \%$ in year two, and, finally, $10 \%$ in year three of transition (See Figure 1). After 1994, Lithuania's GDP grew steadily at an average 5\% through 2002 (Madison, 2003). Out of the four countries we are analyzing, Lithuania had the sharpest decline in GDP; however, it made a respectable rebound. Overall, Lithuania's transitional success with regard to GDP was between below average and average. 
Lithuania's inflation rate was just slightly less than Russia's; however, it was still high enough to raise concerns for hyperinflation early in its transition. Lithuania experienced a level of hyperinflation of $1020 \%$ just one year after the beginning of transition (Balticsworldwide.com) (See Figure 2). After which, the rate of inflation steadily declined to a manageable level. From 1999 to 2005, inflation averaged to less than 5\% (Transition Report Update 2007). We believe that given the information we were able to retrieve on Lithuania's inflation rate, the country did well controlling the inflation rate during the transitional period.

Another downside to Lithuania's transition was its steady rise in unemployment from 1992 to 2001. After peaking at $17.4 \%$ in 2001, unemployment declined slightly, but still hovered between $13 \%$ and $11 \%$ for three years, finally falling to 8.3\% in 2005 (Transition Report Update 2007) (See Figure 3). For a successful transitional economy, one would expect unemployment to peak within the first five to seven years of transition and subsequently decline to a tolerable level. However, this was not the case with Lithuania, and in fact it did not have a successful transition with regard to managing unemployment levels

In general, the highlight of Lithuania's transition was its ability to control the increase in prices. However, the results of other economic indicators negate the success Lithuania had with controlling inflation. The sharp decline and slow recovery of GDP, in combination with inflation growing steadily to $17.4 \%$ in 2001, indicates that the country did not have a successful transition. However, the country did fare much better than Russia's transition.

\section{Russia}

Russia, by far, had one of the toughest transitions out of all of the post-communist countries. There are several plausible reasons why Russia's transition did not go as well as other countries'. One reason could be that the economy had been planned and strictly enforced since the Bolshevik Revolution in 1917, lead by I.V. Lenin, and thus it was the first such nation to experience communism with its citizenry impacted over a longer period of time. Lenin used oppressive force to implement his new socialist regime. Joseph Stalin then took over after Lenin and implemented Communism in many countries after World War II, such as Poland and Czechoslovakia. At the time, Lithuania was a part of the Soviet Union. Another reason could be that the country is so large that implementing such an economic transition "successfully" would be nearly impossible. Yet, a third reason could be the fact that the newly established democratic government faltered when implementing governing policies for the new capitalist economy, such as financial reporting standards. Communism eventually fell in the Soviet Union in 1991, and faced many economic difficulties thereafter.

Russia's GDP took a massive hit once the country started transitioning. Except for one year of positive GDP growth in 1997, GDP fell somewhat dramatically from 1991 through 1998, most notably in 1992 and 1994 when GDP fell by $14.6 \%$ and $12.5 \%$, respectively (See Figure 1). After which, Russia's GDP grew at an average of $7 \%$, which is quite respectable given how severe and protracted its initial economic contraction was (Trumbull, 2008). As of 2002, Russia had only rebounded to almost $80 \%$ of the pre-transitional level of GDP. Thus, it took Russia more than 11 years for Russia to attain the same level of economic output, which is significantly greater than Czech Republic and Poland's recovery time. Thus, Russia's economic transition, as evaluated by analyzing GDP, was far below average and was quite dismal (Trumbull, 2006).

When it came to inflation, the economy didn't fare any better. Coupling the severe and dramatic decline in GDP in 1992 was an astronomical increase in prices. The inflation rate in 1992 was at an astounding 1,490\%. It wasn't until 1996 that Russia's economy was below the 50\% inflation rate threshold to be considered a hyperinflationary economy, and just barely at $45.8 \%$ (See Figure 2). However, there was a very slight glimmer of hope in subsequent years where the inflation rate was just below 20\%, except for 1999 when the inflation rate jumped to $72.4 \%$. Yet again, Russia's transition, in relation to the inflation rate, was quite bleak (Trumbull, 2006).

One strong point to Russia's transition was the unemployment rate. Like most transitional economies, unemployment increased; however, it eventually declined to a manageable level. The only problem, albeit very minor, was the length of time the unemployment rate increased. Unemployment in Post-Soviet Russia increased consistently from 1991 through 1999 (See Figure 3). In 2000, Russia's unemployment rate began to fall. Consequently, we fell that Russia was moderately successful in managing its inevitable unemployment problem (Trumbull, 2008). 
Overall, Russia's transition was one of the worse of any transitional economy. Although Russia managed its unemployment rate during transition, the severe and sharp decline in GDP, coupled with rampant hyperinflation for the first few years of transition, leaves little doubt that Russia's transition was unsuccessful.

\section{HOW THE COUNTRIES CHANGED THEIR REPORTING STANDARDS AS THEY TRANSITIONED}

The transition from a centrally planned economy to a market-oriented economy is a drastic change. Accounting focused on statistics for internal use and after transition they are expected to be published for external users as well. This shift needed a complete modification of standards and the introduction of formerly unknown ideas, such as general accounting principles, regulating bodies and a "true and fair view."

\section{Fourth and Seventh Directives Explained}

The EU's attempt to harmonize accounting involved issuing directives that member countries were required to include in their laws. The results of these directives were the main concern of the EU while the methods to achieve those required results were left up to the member countries (Doupnik \& Perera, 2008). Specifically, two directives are designed to harmonize accounting: The Fourth Directive and the Seventh Directive. The Fourth Directive, which was issued in 1978, dealt with the presentation of financial statements, measurement, disclosure, content, and annual accounts. Notably, the Fourth Directive established the "true and fair view" principle (Doupnik $\&$ Perera, 2008). The "true and fair view" principle requires financial statements to be accurate in the representation of a company's financial position. This principle is of great benefit to stakeholders. The Seventh Directive, adopted in 1983, covers consolidated financial statements and associated companies. According to Black, et al. (2006),

It requires worldwide consolidations, the use of a 'fair value' approach when accounting for assets purchased through acquisitions, the equity treatment of associated corporations, and segmental disclosures of turnover by line of business and geographical business.

\section{Czech Republic}

In 1991, the first Accounting Act was agreed upon by the Czech Parliament, which marked the beginning of the transition from a centrally planned economy to a market economy and a shift away from tax orientation (McGee, 2008). The Czech government was trying to guarantee that their laws were consistent with the laws of the European Commission in order to ensure their membership. New laws were greatly influenced by the Fourth and Seventh Directives because of the urgency to comply with the EC. The government was moving away from accounting that was focused on factual data to assess plan fulfillment and generating statistics for planning purposes. The financial statements were treated as private information before 1989 and a true and fair view, as dictated by the Fourth Directive, did not exist until the movement towards a market economy in 1991.

The Accounting Act covered all business entities and was broken into seven parts. Parts one and two of the Accounting Act set up two forms of accounting: cash based accounting and accrual accounting. Part three let companies know what financial statements were required. Part four specified the valuation methods needed for financial statements and records. Part five explained the model of inventory taking being applied to all assets and liabilities, not just the physical stock. Part six communicated the maintenance of accounting documents and part seven included provisions of temporary, common, and closing aspects (McGee, 2008). Because the Czech Republic has a strong influence on taxes, the Ministry of Finance issued guidelines that were strictly required for taxation before the move towards the EU in 2003. These guidelines included a standardized chart of accounts, procedures to use the chart of accounts and detailed bookkeeping rules, and rules for the preparation, presentation, data included, and notes of the financial statements (McGee, 2008). In 2000, the European Commission adopted a regulation that all listed companies must prepare consolidated financial statements in accordance with the International Accounting Standards Board standards by 2005 and in 2002 the EU adopted a regulation on applying IFRS. Each of these furthered the development of accounting standards.

In 2003, the Czech Republic was further preparing for membership in the EU and was being influenced by the Czech National Accounting Council, which was started by Czech accountants, the Chamber of Auditors, 
Chamber of Tax Advisors, and academics from the University of Economics in Prague (McGee, 2008). Decrees issued by the Ministry of Finance were now a part of the regulatory system, unlike before. Regulation now included the amended Accounting Act and the Decrees, which entailed regulatory guidance for accounting and accounting procedures. The decrees covered different sectors of the economy and regulated accounting until the end of 2003. This switch in the year of 2003 was temporary because of the fundamental change to National Accounting Standards by the end of 2003 .

The regulatory framework was finished at the beginning of 2004 and the regulatory guidance was exchanged for National Accounting Standards. These standards are written and issued by the Ministry of Finance (McGee, 2008). The Czech Republic now has 3 levels of regulation in effect. They are the Accounting Act, Decrees, and National Accounting Standards. The Accounting Act now includes the realization of IAS/IFRS, as the EU requires it. The cash-based accounting that part one and two of the Act set up was eliminated except for tax purposes. The Decrees now call for higher education and qualifications for accountants (McGee, 2008). The Ministry of Finance issues standards without the suggestions of businesses or individuals and separate standards are issued for each type of entity. The Czech Republic is now trying to harmonize their National Accounting Standards with IAS/IFRS and this entails a switch form rules-based accounting to principles-based accounting. To see this harmonization, the Czech Republic will have to set up separate accounting for tax purposes and be able to determine tax base without accounting income (McGee, 2008). The Czech Republic became a member of NATO in 1999. The Czech Republic was admitted into the EU in May 2004. The EU adopted IFRS in 2005 which meant that the Czech Republic had to adopt IFRS as well as all other EU members.

\section{Poland}

Between 1989 and 1991, legislation was passed that started the privatization of Poland. This legislation created a stock exchange in Warsaw, rejuvenated bankruptcy laws, and restructured insurance and banking sectors (Nobes \& Parker, 2002). In 1991 and 1992, corporate and personal income tax laws were passed (Nobes \& Parker, 2002). Poland's Securities Commission, which was set up in 1991 to regulate the stock market, imposed demanding conditions to listed companies. Their Securities Commission was modeled after the United States of America's Securities and Exchange Commission. A law that was passed in 1994 divided up ownership of 500 medium-sized companies into fifteen National Investment Funds (NIF) that were set up by the state and represented the owner of the company (Nobes \& Parker, 2002). All Polish adults were given the opportunity to hold stock in these NIFs.

The Accounting Decree issued by the Ministry of Finance in 1991 covered all entities except financial ones and was highly criticized when it was published for public comment. The Decree needed complementary legislation, only integrated some of the EU fourth Directive requirements and overlooked the seventh Directive. At this time, Poland was not accustomed to consolidated financial statements. The Decree also proved to have inconsistencies with previously passed legislation. The Accounting Decree was superseded in 1994 by the Accounting Act (Nobes \& Parker, 2002).

The Accounting Act was issued to bring Poland closer to meeting EU requirements to be a member. The Act satisfied all missing legislation that was needed and implemented "true and fair view" (Black et al. 2006). Poland became a member of NATO in 1999. The Securities Commission could now make standards for listed companies and should be focusing on disclosure requirements. The Accounting Act of 2002 positioned Poland's accounting standards to be compatible with IFRS, which the EU adopted in 2005. Poland was admitted to the EU in 2004, which required prior harmonization of financial requirements with EU standards and IFRS (Black et al., 2006).

\section{Lithuania}

The Law on the Principles of Accounting in 1992 marked the start of accounting reform in Lithuania. The Law issued requirements on accounting that positioned Lithuania in line with International Accounting Standards and EU Directives. Three principles were imposed: comparability, accrual basis, and going concern (McGee, 2008). The Law also laid the groundwork for valuation and financial statements, including explanatory notes. The Ministry of Finance issued a chart of accounts that was to be used when entities were making financial statements. In 1995, 
the Institute of Audit and Accounting was created to help control development and help prepare standards for accounting and auditing (McGee, 2008).

In 2001, the Law on Accounting, the Law on Financial Accountability of Companies, and the Law on Consolidated Financial Accountability of Companies was issued and advanced Lithuania's accounting reform. These laws dealt with the safekeeping of documents, handling of accounting, the keeping of accounting documents, general accounting principles, preparation of financial statements, evaluation of assets and liabilities, and the conditions for the consolidation of financial statements (McGee, 2008). The Institute of Audit and Accounting was restructured as the Institute of Accounting in 2002. The reasoning behind the restructuring was to reform Lithuania's accounting and harmonize with the EU as quickly as possible. According to McGee (2008), the Institute carries out the following functions:

1. To draw up business accounting standards

2. To prepare methodical recommendations for the financial accounting issues

3. To give suggestions for the preparation of new legal acts, the augmentation of existing ones and for corresponding amendments in the area of accounting and financial accountability

4. To issue periodical, methodical, and another literature on accounting

5. To arrange courses, seminars, conferences, and other professional events

Under the Institute of Accounting, the Board of Standards, the Commission of Experts, and The Committee of Consultation was created. These four groups have the responsibility of announcing Business Accounting Standards, preparing drafts, and submitting opinions. Lithuania's reform was effective and quick enough to meet all EU requirements and be admitted as a member in spring 2004 and Lithuania also became a member of NATO in the same year. Along with Poland and the Czech Republic, Lithuania had to adopt IFRS in 2005 when the EU did so.

\section{Russia}

Accounting began to change in Russia when General Secretary Mikhail Gorbachev announced in 1985 that Russia would be moving from a centrally planned economy to a market-socialist economy, and finally to a freemarket economy in 1991. When Russia had its first exposure to joint ventures in 1988, Russia started changing its accounting to ease ventures between centrally planned economies and capitalist ones. In 1991, noticeable changes began to occur (Enthoven). Russia started to reposition its standards closer to international regulations and made a standard chart of accounts to be used by all companies. The Regulation on Accounting and Reporting in the Russian Federation was passed by government in 1992 which completely altered the existing Russian accounting system. Russia realized they needed more transparency in order to fully move towards Western accounting. Many organizations offered to help their transition, including the Ministry of Finance, international accounting firms, the European Union and the United Nations (Enthoven). As the same for the Czech Republic and Poland, Russia moved towards a multilevel system of accounting. The lower levels are concerned with accounting standards and making sure professionals have the information needed to perform their duties, while the upper levels deal with the conceptual framework and laws concerning auditing and accounting. The Accounting Law, which is on the first level, applies to all bodies in the Russian Federation. It established the regulatory framework, the measurement of assets and liabilities, organizational requirements, and regulations on bookkeeping and reporting (Haller, Raffournier, Walton, 2003). While all of these changes were steps in the right direction, the changes could not be properly implemented without sufficient changes to the country's legal framework as well.

In 1998, the Russian government issued a decree that established their strong position stating that reform was needed. This decree confirmed the need for investors in a market economy and was going to use the International Accounting Standards as their basis for reform (Haller, et. al, 2003). The Tax Code of 1998 was issued in efforts to try and separate tax and accounting to further accounting reform, but taxation is still a major influence on reporting and bookkeeping. This Code organizes all Russian taxes into three divisions; federal taxes, regional taxes, and local taxes (Haller, et. al, 2003). It gives the Russian tax system a structure and defines its principles. Between 1994 and 2001, the Ministry of Finance alone issued 15 Russian Accounting Standards (PBU) which have been revised or are currently under revision. These standards deal with the subjects of dealing with events after the balance sheet date, contingencies, and accounting for fixed assets and inventories, to name a few. 


\section{CURRENT SITUATION WITH REGARD TO ACCOUNTING STANDARDS}

In 2002, the EU issued a directive that required all members to prepare consolidated financial statements according to IFRS by 2005 (Doupnik \& Perera, 2008). The IFRS adopted by the EC includes all International Accounting Standards (IASs) and Standing Interpretations Committee's (SICs) interpretations except IAS 39. The EU adaptation of IAS 39 eradicates requirements dealing with hedge accounting and fair value options. Some EU companies are opting to disclose their use of IFRS as "As Adopted by the EU" (IAS Plus, 2009). Poland, Czech Republic, and Lithuania are required to use IFRS as adopted by the EU for all domestically listed companies. However, for unlisted companies, the requirements vary. Poland requires IFRS for consolidated financial statements of banks and IFRS is permitted for companies that parent uses IFRS or have applied for listing on the stock exchange. For separate financial statements of companies in Poland, IFRS is permitted for those who have applied for listing on the stock exchange or who parent uses IFRS, but is prohibited in separate financial statements of other companies (IAS Plus, 2009). Lithuania requires IFRS for some financial institutions and permits its use for others. The Czech Republic permits IFRS for the use of consolidated financial statements and prohibits its use in separate company statements. Russia currently requires all domestically listed banks to use IFRS, as well as unlisted banks. Other unlisted companies are permitted to prepare financial statements in accordance with IFRS in addition to Russian GAAP financial statements (IAS Plus, 2009).

\section{QUALITATIVE ANALYSIS}

Our analysis will compare the success of the economic transition to the number of accounting standards implemented by each country. Through a qualitative analysis of these comparisons, we will be able to observe whether or not there is a correlation between the two variables.

\section{Czech Republic}

Through our economic analysis, we have discovered that the Czech Republic's economic transition was quite successful. As a result of transition beginning in 1990, their economy's experienced a short collapse in GDP followed by a quick recovery. Eventually, GDP leveled off around late 90s and then subsequently increased past pre-transition level of output around 6 years after transition (Trumbull, 2006). As for the economic stability assessment, unemployment increased over time while inflation steadily decreased over time (See Figures 1 through $3)$.

While transitioning, the Czech Republic had three main transition periods with regard to implementing accounting standards. Between 1991 and 2002, the Czech Republic implemented a one-level type of accounting regulation, which was comprised of the Czech Accounting Act. In 2003, the Czech Republic promulgated additional accounting decrees that coupled the Accounting Act. In 2003, laws implementing national accounting standards were passed (McGee, 2008). Finally, International Financial Reporting Standards were adopted by the Czech Republic in 2005.

Overall, there is a positive correlation between how well the country transitioned and the number of accounting laws and standards implements.

\section{Poland}

Poland's transition, which began in 1989, was similar to the Czech Republic's. GDP collapsed in the first year of economic transition, subsequently followed by steady growth. Like the Czech Republic, Poland also returned to pre-transition levels of GDP about six years after the beginning of transition. Unemployment, however, steadily increased overtime, while inflation ballooned to hyperinflationary levels in the first year of transition and greatly decreased shortly thereafter (See Figures 1 through 3 ).

Poland implemented several accounting laws and regulations between 1989 and 2005. Among the topics that were covered in the Polish accounting regulations were principles of accounting, companies with foreign shareholding, stock exchange listings, examination and disclosure of financial reports, taxation of legal entities, 
fixed assets, and intangibles. In 2002, Poland started harmonizing their accounting standards with IFRS to prepare for its entry into the EU in 2004. In 2005, Poland adopted IFRS.

After comparing the economic results of transition to the development of financial reporting standards in Poland, we believe that there is a correlation between how well the country transition and the number of accounting regulations implemented during that time frame.

\section{Lithuania}

Lithuania's transition was somewhat unsuccessful. With transition beginning in 1991, the country's GDP experienced an initial severe contraction and recovered very well, albeit not to pre-transition levels of GDP within the first 12 years of transition. Unemployment in Lithuania was quite high initially but later decreased while inflation increased steadily over time (See Figures 1 through 3).

With regard to Lithuania's implementation of accounting standards during transition, the country implemented quite a few laws and regulations to help govern financial reporting. Over time, Lithuania had implemented 20 Business Accounting Standards, which include regulation on the financial statement, the balance sheet, intangible assets, correction of errors, and consolidated financial statements. In addition, they had implemented 10 General Accounting Principles, which are very similar to the conceptual framework established in the United States Generally Accepted Accounting Principles.

We've established that Lithuania's transition was unsuccessful; however, the country established numerous accounting regulations over the course of the economic transition. Although this Lithuania's case is a negative correlation, we believe that generally there should still be a positive correlation between how well a country transitions and the number of accounting laws and standards a country implements. Our argument with Lithuania being an exception is that the country not only started transitioning one to two years later than Poland and the Czech Republic, but also waited a year before implementing their accounting standards. This could be an explanation for why their transition was unsuccessful while still promulgating a number of accounting laws and regulations.

\section{Russia}

Russia had one of the worse economic transitions out of all of the former socialist nations. Shortly after the beginning of their transition in 1991, GDP collapsed over a lengthy number of years and was quite severe. Russia maintained their unemployment numbers quite decently, with unemployment peaking at $13.4 \%$ in 1999 (Trumbull, 2008). Russia experienced terrible hyperinflation in the first 5 years of transition, subsequently declining to around $20 \%$ in 2005 (Trumbull, 2008) (See Figures 1 through 3).

Russia, like Lithuania, began transitioning later than Czech Republic and Poland and waited one year before implanting the Regulation on Accounting and Reporting Act in 1992. The Ministry of Finance implemented 15 accounting standards between 1994 and 2001, with a new tax code and a decree basing their national accounting standards on IFRS being passed in 1998. The fact that Russia had passed so many accounting laws within that time period proves to be inconsequential because Russia's Ministry of Finance was the standard setting body as well as the regulatory body.

In conclusion, the success of Russia's transition is not correlated with the number of financial reporting standards implemented. However, even though Russia implemented a number of financial reporting standards, the economy could have still suffered as a result of waiting too long to transition and implement new accounting regulation. Additionally, since the Ministry of Finance had control of setting standards as well as regulating those standards, this clearly presents a risk for manipulation of financial accounting in Russia.

\section{CONCLUSION}

Through our economic analysis and research on each country's development of accounting standards and regulations, we can conclude that there is a correlation between the success of a county's transition and the development of its framework of accounting. Analysis of the Czech Republic and Poland proved that there is a very 
strong correlation between the two variables. According to their economic indicators, both countries had a very successful transition. Additionally, both countries quickly implemented accounting regulations over the course of their transition.

In contrast, Lithuania and Russia both had weaker correlations. We concluded that each country transitioned unsuccessfully due to its changes in GDP, unemployment, and inflation during transition. However, both countries implemented a number of accounting standards during their transition. It is worth noting that Lithuania and Russia both began transition one to two years later than Poland and the Czech Republic. Furthermore, Russia and Lithuania both waited one more year after the beginning of transition before implementing any major accounting laws and regulations. Both reasons could explain why the correlation is weak.

Inherently, there were limitations to our research. Due to other qualitative variables which could not be calculated, such as the country's morale and willingness to transition, we were be unable to fully prove whether or not there is an exact correlation between the number of accounting standards and regulations promulgated and success of a country's transition. Furthermore, our study was limited by the time frame of an academic semester. As a result, we could not perform a full-scale research on this subject, which might include whether or not there is a cause and effect between the two variables. Also, we were unable to find any information on regulatory bodies, such as the European Anti-Fraud Office (OLAF), in a timely manner, which would have given us more specific information on how accounting standards are regulated in each country and in the EU. Lastly, future research on the topic of transitional economies of Europe and the development of financial reporting standards should focus on the limitations to our analysis.

Figure 1

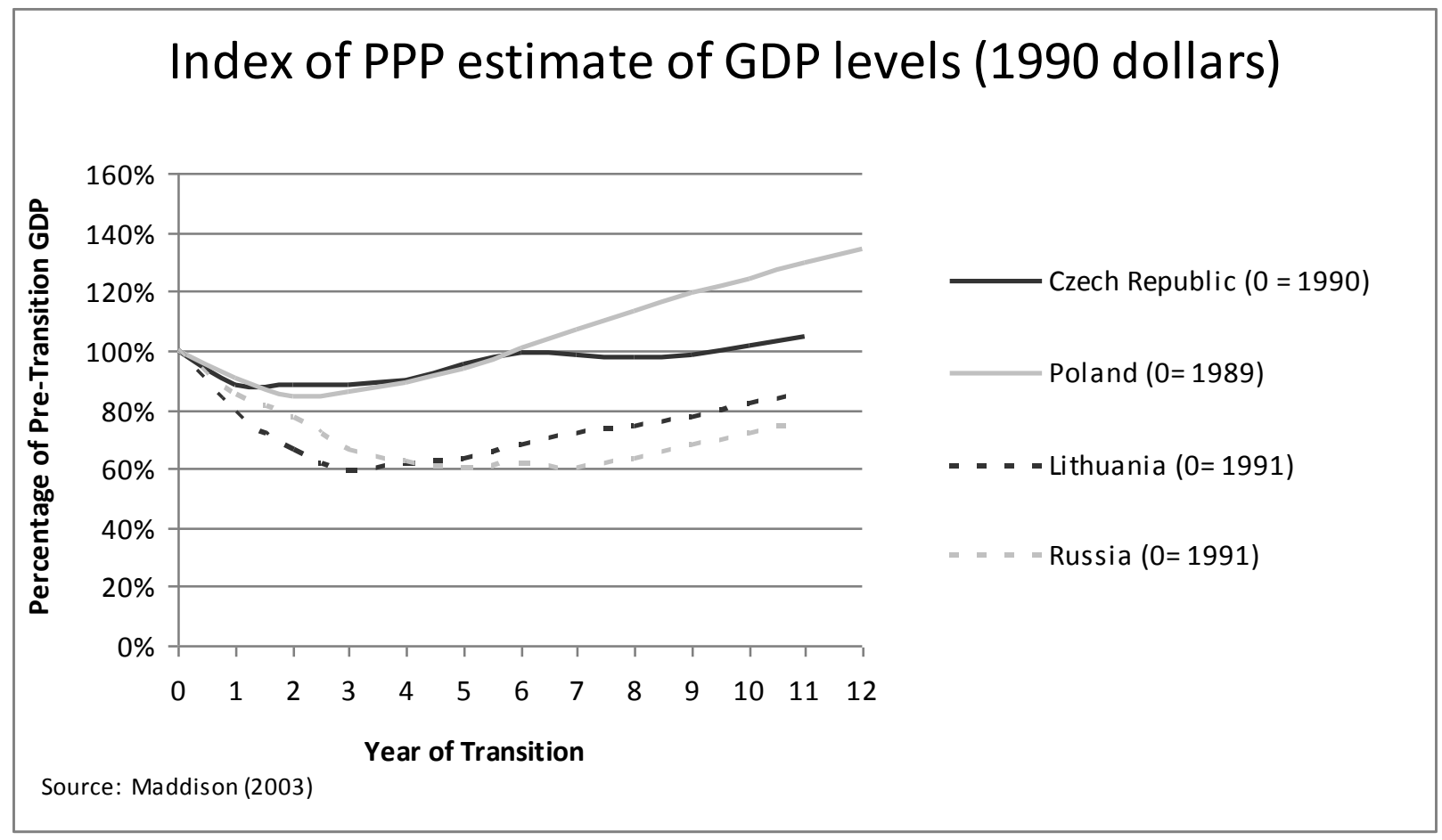


Figure 2

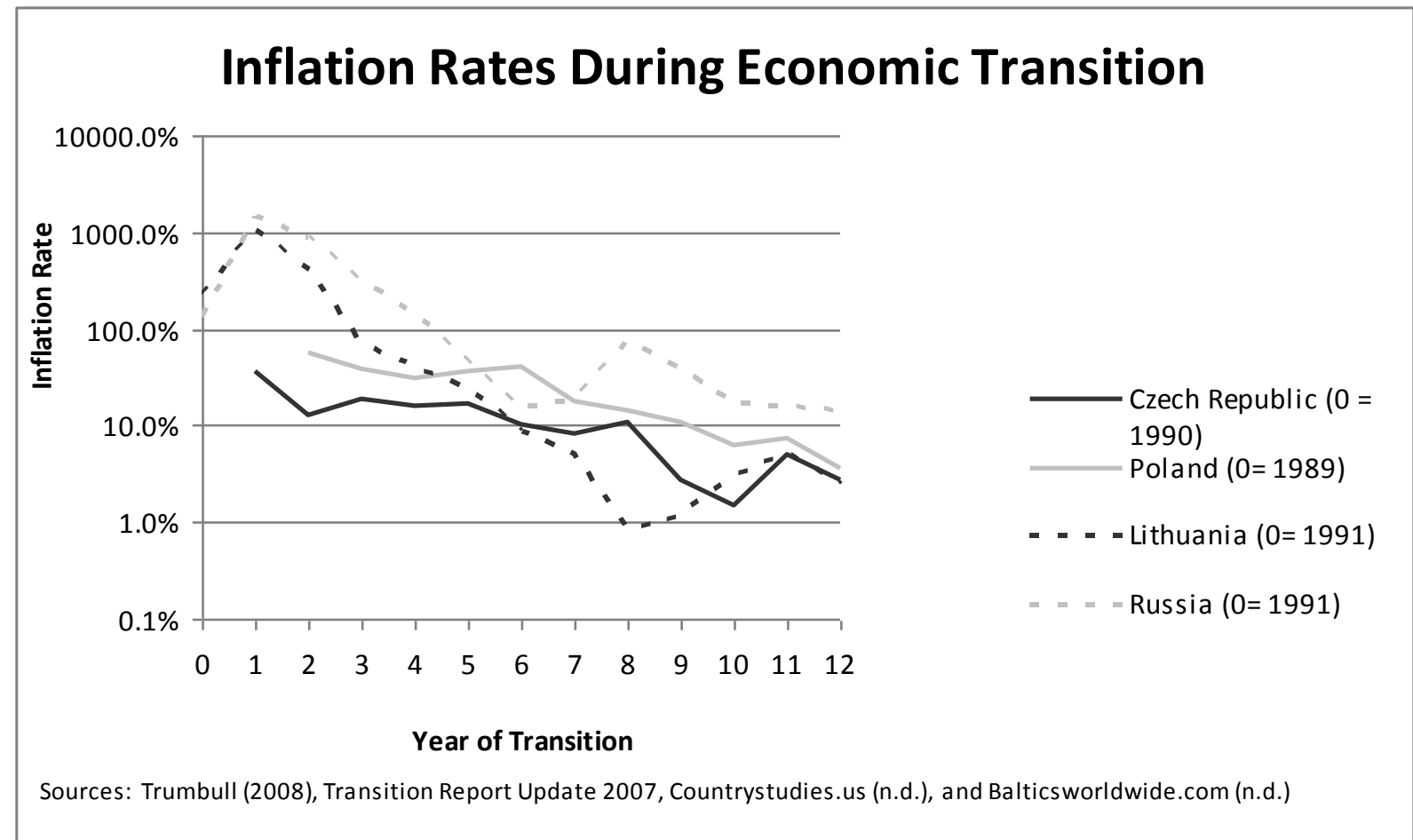

Figure 3

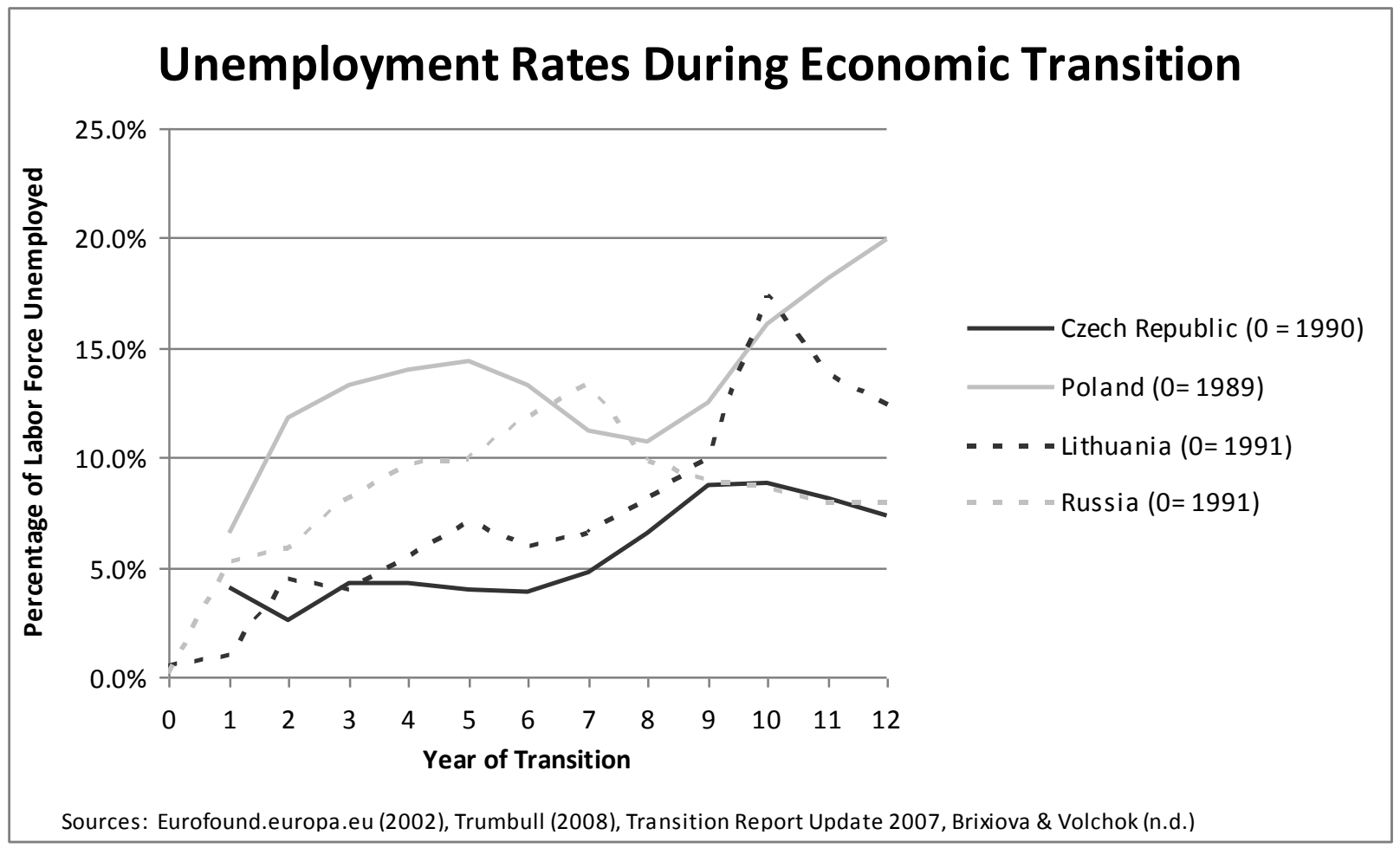




\section{AUTHOR INFORMATION}

Tristan Gartin is an undergraduate at West Virginia University pursuing a degree in Business Administration with a major in Accounting. She is a member of Beta Gamma Sigma, a West Virginia Promise Scholar, and has been recognized on the President's academic list in all of her undergraduate semesters.

Evan Shroyer graduated Summa Cum Laude in 2008 with a degree in Business Administration with a major in Accounting and a minor in Economics from West Virginia University. Currently, he is completing a Master of Professional Accountancy and a Graduate Certification in Forensic Accounting and Fraud Investigation at West Virginia University. In October of 2009, he will begin work at KPMG in Washington, D.C., as a forensic accountant.

Presha E. Neidermeyer, Ph.D. CPA is a faculty member in the Division of Accounting within West Virginia University's College of Business and Economics. Her research specialty includes the impact of culture on behavior and gender issues, which are published in numerous journals. She is the co-author of Use What You Have: Resolving the HIV/AIDS Pandemic. Her teaching specialties include financial and international accounting. She is an active participant in various organizations benefiting charities in Africa. She has led multiple teams to Africa of business people interested in using their special skills to help minimize the impact of the AIDS Pandemic.

\section{REFERENCES}

1. Baltic Economic Indicators. (n.d.). Retrieved April 19, 2009, from http://www.balticsworldwide.com/baltic-economic-indicators/

2. Black, E. L., Gray, S. J., \& Radebaugh, L. H. (2006). International Accounting and Multinational Enterprises. New York, NY: Wiley.

3. Brixiova, Z., \& Volchok, V. (n.d.). Labor Market Trends in Belarus. Retrieved April 15, 2009, from www.imf.org/external/country/blr/rr/pdf/101504.pdf

4. $\quad$ CIA - The World Factbook. (n.d.). Retrieved April 15, 2009, from https://www.cia.gov/library/publications/the-world-factbook/print/lh.html

5. Doupnik, T., \& Perera, H. (2008). International Accounting. New York: McGraw-Hill/Irwin.

6. Economic Reforms. (n.d.). Retrieved April 19, 2009, from http://www countrystudies.us/lithuania/15.html

7. Enthoven, Adolf J. H. (n.d.). The Russian Revolution in Accounting and Auditing. Retrieved April 15, 2009, from http://www.worldbank.org/html/prddr/trans/janfeb99/pgs22-25.htm.

8. Gardawski, J. (2002, October 29). The dynamics of unemployment from 1990 to 2002. Retrieved April 19, 2009, from http://www.eurofound.europa.eu/eiro/2002/10/feature/p10210110f.htm

9. Haller, A., Raffournier, B., \& Walton, P. (2003). International Accounting. New York: Cengage Learning Business Press.

10. IAS Plus - Use of IFRSs by Jurisdiction - Domestic Listed and Unlisted Companies. (2009, March 24). Retrieved April 13, 2009, from http://www.iasplus.com/country/useias.htm\#*

11. Maddison, A. (2003). Development Centre Studies The World Economy: Historical Statistics (Development Centre Studies). Paris: Org. For Economic Cooperation \& Development.

12. McGee, R. W. (2008). Accounting Reform in Transition and Developing Economies. New York: Springer.

13. Nobes, C., \& Parker, R. B. (2002). Comparative International Accounting (7th Edition). Alexandria, VA: Prentice Hall.

14. Pallis, D. (n.d.). The Trade-Off between Inflation and Unemployment in the New European Union Member-States. Retrieved April 15, 2009, from www.eurojournals.com/IRJFE 1 - 8 Pallis.pdf

15. Transition Report Update 2007. (n.d.). Retrieved April 15, 2009, from www.ebrd.com/pubs/econo/tru07.pdf

16. Trumbull, W. (Spring 2008). Economics 453: Transitional Economies of Europe, West Virginia University, Morgantown, WV.

17. Trumbull, W., \& Leeson, P. (2006). Comparing Apples: Normalcy, Russia, and the Remaining PostSocialist World. Post-Soviet Affairs, 22(3), 225-248. 
NOTES 